\title{
Dinitrogen fixation in aphotic oxygenated marine environments
}

\section{Eyal Rahav ${ }^{1,2}$, Edo Bar-Zeev ${ }^{1+}$, Sarah Ohayon ${ }^{1}$, Hila Elifantz ${ }^{1}$, Natalia Belkin ${ }^{1}$, Barak Herut ${ }^{2}$, Margaret R. Mulholland ${ }^{3}$ and llana Berman-Frank ${ }^{1 *}$}

${ }^{1}$ Mina and Everard Goodman Faculty of Life Sciences, Bar-Ilan University, Ramat Gan, Israel

2 Israel Oceanographic and Limnological Research, National Institute of Oceanography, Haifa, Israel

${ }^{3}$ Department of Ocean, Earth and Atmospheric Sciences, Old Dominion University, Norfolk, VA, USA

Edited by:

George S. Bullerjahn, Bowling Green

State University, USA

Reviewed by:

Michael R. Twiss, Clarkson

University, USA

Robinson W. Fulweiler, Boston

University, USA

\section{*Correspondence:}

Ilana Berman-Frank, Mina and

Everard Goodman Faculty of Life

Sciences, Bar-Ilan University,

Ecology Building 201, Ramat Gan

52900, Israel

e-mail: ilana.berman-frank@biu.ac.il

${ }^{\dagger}$ Present address:

Edo Bar-Zeev, Department of Chemical and Environmental Engineering, Yale University, New Haven, CA, USA
We measured $\mathrm{N}_{2}$ fixation rates from oceanic zones that have traditionally been ignored as sources of biological $\mathrm{N}_{2}$ fixation; the aphotic, fully oxygenated, nitrate $\left(\mathrm{NO}_{3}^{-}\right)$-rich, waters of the oligotrophic Levantine Basin (LB) and the Gulf of Aqaba (GA). $N_{2}$ fixation rates measured from pelagic aphotic waters to depths up to $720 \mathrm{~m}$, during the mixed and stratified periods, ranged from $0.01 \mathrm{nmol} \mathrm{N} \mathrm{L} \mathrm{L}^{-1} \mathrm{~d}^{-1}$ to $0.38 \mathrm{nmol} \mathrm{N} \mathrm{L} \mathrm{N}^{-1} \mathrm{~d}^{-1}$. $\mathrm{N}_{2}$ fixation rates correlated significantly with bacterial productivity and heterotrophic diazotrophs were identified from aphotic as well as photic depths. Dissolved free amino acid amendments to whole water from the GA enhanced bacterial productivity by 2-3.5 fold and $\mathrm{N}_{2}$ fixation rates by $\sim 2$-fold in samples collected from aphotic depths while in amendments to water from photic depths bacterial productivity increased 2-6 fold while $\mathrm{N}_{2}$ fixation rates increased by a factor of 2 to 4 illustrating that both BP and heterotrophic $\mathrm{N}_{2}$ fixation were carbon limited. Experimental manipulations of aphotic waters from the LB demonstrated a significant positive correlation between transparent exopolymeric particle (TEP) concentrations and $\mathrm{N}_{2}$ fixation rates. This suggests that sinking organic material and high carbon $(\mathrm{C})$ : nitrogen $(\mathrm{N})$ micro-environments (such as TEP-based aggregates or marine snow) could support high heterotrophic $\mathrm{N}_{2}$ fixation rates in oxygenated surface waters and in the aphotic zones. Indeed, our calculations show that aphotic $\mathrm{N}_{2}$ fixation accounted for 37 to $75 \%$ of the total daily integrated $\mathrm{N}_{2}$ fixation rates at both locations in the Mediterranean and Red Seas with rates equal or greater to those measured from the photic layers. Moreover, our results indicate that that while $\mathrm{N}_{2}$ fixation may be limited in the surface waters, aphotic, pelagic $\mathrm{N}_{2}$ fixation may contribute significantly to new $\mathrm{N}$ inputs in other oligotrophic basins, yet it is currently not included in regional or global $\mathrm{N}$ budgets.

Keywords: dinitrogen fixation, diazotrophs, aphotic layer, oligotrophic, heterotrophic diazotrophs

\section{INTRODUCTION}

In many of the world's oceans, the availability of dissolved inorganic nitrogen $(\mathrm{N})$ controls primary production in surface waters (Falkowski, 1997; Karl et al., 2002). This is because the most abundant form of $\mathrm{N}$ in the oceans, dinitrogen $\left(\mathrm{N}_{2}\right)$, is biologically unavailable to the majority of organisms that reside there. Subgroups of prokaryotic organisms (diazotrophs) fix $\mathrm{N}_{2}$ and convert it to ammonium via the nitrogenase enzyme complex. This biological process is an important source of "new" $\mathrm{N}$ to oceanic systems that can stimulate production and growth of microbial communities. Current models suggest that new $\mathrm{N}$ inputs from $\mathrm{N}_{2}$ fixation by cyanobacterial diazotrophs in the upper photic layers of the oceans is about $130-140 \mathrm{Tg} \mathrm{N} \mathrm{y^{-1 }}$ (Gruber, 2008; Eugster and Gruber, 2012).

Globally, on geologic timescales, $\mathrm{N}$ inputs via $\mathrm{N}_{2}$ fixation are thought to be balanced by $\mathrm{N}$ losses via denitrification (Falkowski, 1997; Deutsch et al., 2007). However, at present, rate measurements suggest that $\mathrm{N}$ losses from the ocean via denitrification $\left(\sim 245-322 \mathrm{Tg} \mathrm{N} \mathrm{y}^{-1}\right)$ far exceed $\mathrm{N}$ inputs via $\mathrm{N}_{2}$ fixation and terrestrial sources (Codispoti et al., 2001; Gruber and Galloway, 2008). The balance between $\mathrm{N}_{2}$ fixation and denitrification (including annamox) is considered to critically impact the oceanic inventory of bioavailable nitrogen and thus primary productivity (PP) in the oceans (Gruber and Galloway, 2008).

Current models generally restrict oceanic $\mathrm{N}_{2}$ fixation to the surface, sunlit, photic layer of the oceans where autotrophic cyanobacterial diazotrophs occur (Gruber, 2008). However, recent work suggests that prokaryotic $\mathrm{N}_{2}$ fixers are more widely distributed geographically than previously thought (Moisander et al., 2010; Mulholland et al., 2012) and diazotrophs have been identified from more diverse pelagic environments including aphotic pelagic waters in oxygen minimum zones (OMZ) (Hamersley et al., 2011; Jayakumar et al., 2012). While it is known that diazotrophs inhabit shallow benthic environments and microbial mats (Capone, 1983; Bebout et al., 1987; Herbert, 1999), sea grass communities (McGlathery, 2008), coral reefs (O'Neil and Capone, 2008), and even hydrothermal vent communities (Mehta and Baross, 2006), the small areal extent of 
these habitats is thought to limit their contribution to marine $\mathrm{N}_{2}$ fixation (Brooks et al., 1971; Carpenter and Capone, 2008).

For many years, investigations of marine $\mathrm{N}_{2}$ fixation also focused on oligotrophic oceanic regions because the presence of fixed $\mathrm{N}$ was considered inhibiting to active $\mathrm{N}_{2}$ fixation (Mulholland and Capone, 1999; Flores and Herrero, 2005; Ward et al., 2009). Oligotrophic regions harbor a variety of cyanobacterial diazotrophs including the filamentous cyanobacteria Trichodesmium spp., diatom-diazotroph associations (DDA's), and unicellular cyanobacteria such as Croccosphaera and group A cyanobacteria (UCYN-A) (Bar-Zeev et al., 2008; Carpenter and Capone, 2008; Zehr et al., 2008). However, even Trichodesmium, the most widely studied marine diazotroph, can fix $\mathrm{N}_{2}$ when ambient inorganic $\mathrm{N}$ concentrations are on $\sim 5 \mu \mathrm{M}$ (Mulholland et al., 2001), conditions rarely reached in most oceanic photic realms. $\mathrm{N}_{2}$ fixation of marine diazotrophs has been observed in nutrient replete cultures (Mulholland et al., 2001) and systems with high dissolved inorganic N concentrations (Voss et al., 2004; Rees et al., 2009; Mulholland et al., 2012). Data compilation from euphotic, mesopelagic, and benthic studies shows that $\mathrm{NO}_{3}^{-}$and $\mathrm{NH}_{4}^{+}$concentrations, up to 30 and $200 \mu \mathrm{M}$ respectively, can result in $\mathrm{N}_{2}$ fixation rates similar to those found in nitrate depleted surface waters (reviewed in Knapp, 2012). Moreover, different sensitivities to DIN concentrations, exposure time, and compensation mechanisms all suggest that dissolved $\mathrm{N}$ concentrations do not control diazotroph distribution and activities in many marine environments (Knapp, 2012).

In addition to photoautotrophic diazotrophs that have been previously considered the dominant $\mathrm{N}_{2}$ fixers in marine systems (Carpenter and Capone, 2008), heterotrophic diazotrophs from $\alpha, \beta, \gamma, \delta$, and $\varepsilon$-proteobacterial phylogenies, as well as methanogenic archaea contribute to marine $\mathrm{N}_{2}$ fixation including benthic and pelagic realms, mesotrophic and eutrophic environments (Chien and Zinder, 1996; Wu et al., 2003; Zehr et al., 2003; Halm et al., 2012). Heterotrophic diazotrophs have been identified from $\mathrm{NO}_{3}$-rich deep, aphotic zones of the oceans (Riemann et al., 2010), including OMZ (Jayakumar et al., 2012) and from near hydrothermal vents (Mehta et al., 2005). In the subtropical Atlantic, cyanobacterial nifH genes dominated the photic layer (Langlois et al., 2005); while bacterial nifH genes dominated the deep aphotic zones (Riemann et al., 2010). In the ultraoligotrophic South Pacific Gyre (SPG) sequence analyses of nifH genes and their expressed transcripts revealed a prevalence of heterotrophic diazotrohic $\gamma$-proteobacteria (Cluster I-Zehr et al., 2003) and the unicellular photoheterotrophic Group A cyanobacteria (UCYN-A) down to $200 \mathrm{~m}$ - the deep chlorophyll maximum (Halm et al., 2012).

While the presence of diazotrophs in oceanic aphotic zones has been demonstrated, to our knowledge, only three published studies have actually measured rates of $\mathrm{N}_{2}$ fixation in aphotic environments; one study was conducted in the Eastern Tropical Pacific (Fernandez et al., 2011), another in the Southern California Bight (Hamersley et al., 2011), and the third in a hydrothermal vent community (Mehta and Baross, 2006). The first two studies were located in OMZ or hypoxic areas. In the Southern California Bight aphotic $\mathrm{N}_{2}$ fixation accounted for up to one-third of the total areal rates of $\mathrm{N}_{2}$ fixation $\left(55 \mu \mathrm{mol} \mathrm{N} \mathrm{m} \mathrm{m}^{-2} \mathrm{~d}^{-1}\right.$ out of
$150 \mu \mathrm{mol} \mathrm{N} \mathrm{m}^{-2} \mathrm{~d}^{-1}$ ) (Hamersley et al., 2011). While in the nutrient-rich OMZ of the Eastern Tropical South Pacific (ETSP), $\mathrm{N}_{2}$ fixation rates from sub-surface oxygen deficient waters contributed about 5 times more $\mathrm{N}$ than $\mathrm{N}_{2}$ fixation from the oxic photic layer (Fernandez et al., 2011). Moreover, $\mathrm{N}_{2}$ fixation cooccurred spatially and temporally with denitrification in the ETSP (Fernandez et al., 2011), refuting the paradigm of spatial and/or temporal uncoupling between the two processes.

In oligotrophic environments such as the Levantine Basin (LB) (Eastern Mediterranean Sea, EMS) and the Gulf of Aqaba (northern Red Sea, GA), primary production in surface waters is limited at times by nitrogen $(\mathrm{N})$, phosphorus $(\mathrm{P})$, or co-limited by both (Paytan et al., 2009; Krom et al., 2010; Tanaka et al., 2011). Denitrification in subsurface waters is absent because waters are fully oxygenated (Kress and Herut, 2001; Al-Qutob et al., 2002). In the EMS, new nitrogen inputs via $\mathrm{N}_{2}$ fixation in the photic zone are generally very low, with rates ranging from 0.01 to $0.3 \mathrm{nmol}$ $\mathrm{N} \mathrm{L}^{-1} \mathrm{~d}^{-1}$. These rates contribute only $1-2 \%$ of new production in the LB (Yogev et al., 2011; Berman-Frank and Rahav, 2012; Rahav et al., 2013a). Although occasional small blooms of Trichodesmium and DDA's occur in the GA, $\mathrm{N}_{2}$ fixation rates are still relatively low ranging from $\sim 0.05$ to $2 \mathrm{nmol} \mathrm{N} \mathrm{L}^{-1} \mathrm{~d}^{-1}$ (Post et al., 2002; Foster et al., 2009). In the photic layer of the EMS and the GA, diazotroph populations include cyanobacteria as well as many heterotrophic microbes (Man-Aharonovich et al., 2007; Foster et al., 2009; Yogev et al., 2011).

In this study we measured $\mathrm{N}_{2}$ fixation rates in the aphotic, oxygenated waters of the oligotrophic LB and the GA. Our results demonstrate significant $\mathrm{N}_{2}$ fixation rates equal or greater to those measured from the photic layers and a prevalence of heterotrophic diazotrophs. This initial data suggests the aphotic oxygenated zones can be considerable sources of new $\mathrm{N}$ supporting biological production in oligotrophic waters.

\section{MATERIALS AND METHODS SAMPLING LOCATIONS}

Seawater samples were collected from two representative pelagic stations that were sampled several times during the mixed and stratified periods; one in the GA in the Red Sea and one in the LB in the Eastern Mediterranean Sea (Table 1 and below). Water samples were collected using $10 \mathrm{~L}$ Niskin bottles mounted on a rosette equipped with a CTD (Seabird 19 Plus) and fluorometer (Turner designs, Cyclops7) to measure hydrographic properties of the water column, and an in situ PAR sensor (QSP-2300, Biospherical Instruments Inc) allowing distinction between the photic and aphotic zones.

Gulf of Aqaba (GA) - Water samples from the GA were collected aboard the $R / V$ Sam Rothberg at a station located at the northern tip of the Red Sea (Station A $29^{\circ} 55^{\prime} \mathrm{N}, 34^{\circ} 28^{\prime} \mathrm{E}$ ) during the winter when the water column was well-mixed (March 2010) and twice during the stratified summer period (September 2010 and July 2012).

Levantine Basin (LB)-Samples from the LB were collected during cruises aboard the $R / V$ Mediterranean Explorer and the $R / V$ Shikmona. A station located west of the Israeli coastline (Station OUT; $32^{\circ} 57^{\prime} \mathrm{N}, 34^{\circ} 45^{\prime} \mathrm{E}$ ) was sampled during periods when the water column was well mixed (December 2010, 
Table 1 | Summary of the sampling dates, locations, and depths.

\begin{tabular}{|c|c|c|c|c|c|c|c|}
\hline \multirow{2}{*}{$\begin{array}{l}\text { Region } \\
\text { Red Sea }\end{array}$} & \multicolumn{2}{|c|}{ Sampling location } & \multirow{2}{*}{$\begin{array}{l}\text { Sampling } \\
\text { duration }\end{array}$} & \multirow{2}{*}{$\begin{array}{l}\text { Bottom } \\
\text { depth }(\mathbf{m})\end{array}$} & \multirow{2}{*}{$\begin{array}{l}\text { Photic depths } \\
\text { sampled (m) }\end{array}$} & \multirow{2}{*}{$\begin{array}{l}\text { Aphotic depths } \\
\text { sampled (m) }\end{array}$} & \multirow{2}{*}{$\begin{array}{l}\text { Depth of } \mathbf{0 . 1 \%} \\
\text { light }(\mathbf{m})\end{array}$} \\
\hline & Gulf of Aqaba & $29^{\circ} 55 \mathrm{~N}^{\prime}$ & & & & & \\
\hline & & & July 2012 & & 10,85 & $160,300,500,720$ & 100 \\
\hline \multirow[t]{4}{*}{ Med. Sea } & \multirow{4}{*}{$\begin{array}{l}\text { Levantine } \\
\text { basin (LB) }\end{array}$} & $32^{\circ} 57 N^{\prime}$ & Dec. 2010 & \multirow[t]{4}{*}{1100} & $0,20,50,100$ & 300,500 & 110 \\
\hline & & & Feb. 2012 & & 5 & 300 & 110 \\
\hline & & & Apr.2012 & & 5 & 300 & 110 \\
\hline & & & Mar. 2013 & & 5,80 & 250 & 100 \\
\hline
\end{tabular}

Additional details are available in the Material and methods section. Med. Sea, Mediterranean Sea.

February 2012, March 2013) and stratified (August 2011, October 2011, April 2012).

\section{INORGANIC NUTRIENTS}

Duplicate unfiltered water samples were collected in $15-\mathrm{mL}$ acid-washed plastic scintillation vials and immediately frozen at $-20^{\circ} \mathrm{C}$ until they were analyzed with a segmented flow Skalar SANplus System Instrument as detailed in Kress and Herut (2001). The precisions of nitrate+ nitrite (hereafter $\mathrm{NO}_{3}$ ), orthophosphate $\left(\mathrm{PO}_{4}\right)$ and silicic acid $\left(\mathrm{Si}(\mathrm{OH})_{4}\right)$ measurements were $0.02,0.003$ and $0.06 \mu \mathrm{M}$, respectively. The limits of detection were $0.075 \mu \mathrm{M}, 0.008 \mu \mathrm{M}$ and $0.03 \mu \mathrm{M}$ for $\mathrm{NO}_{3}, \mathrm{PO}_{4}$ and $\mathrm{Si}(\mathrm{OH})_{4}$, respectively.

\section{DINITROGEN $\left(\mathrm{N}_{2}\right)$ FIXATION RATES}

Rates of $\mathrm{N}_{2}$ fixation were measured in field- collected samples (4.5 L) using the ${ }^{15} \mathrm{~N}_{2}$ bubble addition technique described by Montoya et al. (1996) and Mulholland et al. (2006) using highly enriched ${ }^{15} \mathrm{~N}_{2}$ gas (99\%). The seawater was dispensed into $4.5 \mathrm{~L}$ Nalgene incubation bottles, $9 \mathrm{~mL}$ of ${ }^{15} \mathrm{~N}_{2}$ was added, and bottles were then placed in an incubator with continuously flowing seawater to maintain ambient surface-water temperatures. Triplicate bottles were used for each depth sampled. The incubator was shaded with neutral density screening to simulate ambient irradiance conditions at the depths from which samples were collected. For samples collected from the aphotic layer, bottles were incubated in the dark. Both light and dark incubations were $24-48 \mathrm{~h}$ in duration. While the bubble method may underestimate $\mathrm{N}_{2}$ fixation (Mohr et al., 2010; Großkopf et al., 2012; Wilson et al., 2012), particularly during short incubations (hours), our long incubation times should have minimized this problem (Mulholland et al., 2012; Rahav et al., 2013b). See also the discussion regarding underestimation of rates due to the bubble vs. enriched seawater method (Mohr et al., 2010). To terminate the incubations, water was filtered onto pre-combusted $25 \mathrm{~mm} \mathrm{GF} / \mathrm{F}$ filters $\left(450^{\circ} \mathrm{C}\right.$ for $4 \mathrm{~h}$ ). Filters were dried and pelletized in tin disks and analyzed on a Europa 20/20 mass spectrometer equipped with an automated nitrogen and carbon analyzer preparation module. $\mathrm{N}_{2}$ fixation was calculated using a mixing model (Orcutt et al., 2001) as described by Mulholland et al. (2006) with $\mathrm{N}$ solubility factors according to Weiss (1970).
Depth-integrated $\mathrm{N}_{2}$ fixation rates were based on measurements made at 3 to 6 water column depths spanning both photic and aphotic layers. In months where $\mathrm{N}_{2}$ fixation measurements were made at only 2 depths, no such calculations were made (i.e., Not Available, N.A; Table 2). Depth-integrations included only the portion of the water column sampled (range was 150- $720 \mathrm{~m}$ in depth) and did not extend to the bottom except for one case in the GA during July 2012, when $\mathrm{N}_{2}$ fixation rates were measured also in bottom waters (Table 1 ). The percent contribution of the aphotic $\mathrm{N}_{2}$ fixation was calculated by difference after subtracting out the contribution of photic $\mathrm{N}_{2}$ fixation from the total integrated water column $\mathrm{N}_{2}$ fixation rate.

\section{PRIMARY PRODUCTIVITY}

Photosynthetic carbon fixation rates were estimated using ${ }^{13} \mathrm{C}$ labeled bicarbonate (Mulholland and Bernhardt, 2005). Water samples were placed in triplicate clear $4.5 \mathrm{~L}$ polycarbonate Nalgene bottles and amended with $99 \% \mathrm{NaH}^{13} \mathrm{CO}_{3}$ (Sigma) to obtain enrichments of about $1 \%$ of the ambient dissolved inorganic carbon pool. Bottles were incubated under the same conditions as for the ${ }^{15} \mathrm{~N}_{2}$ incubation bottles described above. Parallel dark bottles were also incubated for photic depths. As for ${ }^{15} \mathrm{~N}_{2},{ }^{13} \mathrm{C}$ incubations were terminated by immediately filtering the entire contents of incubation bottles onto pre-combusted $25 \mathrm{~mm} \mathrm{GF} / \mathrm{F}$ filters $\left(450^{\circ} \mathrm{C}\right.$ for $\left.4 \mathrm{~h}\right)$. Filters were stored at $-20^{\circ} \mathrm{C}$ and then dried and pelletized in tin disks prior to their analysis on the Europa 20/20 mass spectrometer. Rates of C uptake were calculated using a mixing model (as described above) and dark carbon fixation was subtracted from the light carbon fixation rates for photic incubations.

\section{BACTERIAL PRODUCTIVITY}

Bacterial production was estimated using the ${ }^{3} \mathrm{H}$-leucine (Amersham, Specific activity: $160 \mathrm{Ci} \mathrm{mmol}{ }^{-1}$ ) incorporation method (Simon et al., 1990). Triplicate $1.7 \mathrm{ml}$ samples were incubated for $4-8 \mathrm{~h}$ at in situ temperatures in the dark. Triplicate, trichloroacetic acid (TCA) killed samples (Sigma T9159) served as controls. One $\mathrm{ml}$ of high ${ }^{3} \mathrm{H}$ affinity scintillation cocktail (ULTIMA-GOLD) was added to samples and they were counted using a TRI-CARB 2100 TR, PACKARD scintillation counter. 
Table 2 | Measured physical, chemical, and biological properties of the photic and aphotic layers from the sampling stations in the Levantine basin and the Gulf of Aqaba averaged seasonally for when the water column was mixed (winter) and during thermal stratification (spring, summer, and fall).

\begin{tabular}{|c|c|c|c|c|c|c|c|c|c|c|}
\hline Location & Depth & Period & $\begin{array}{l}\text { Temp. } \\
\left({ }^{\circ} \mathrm{C}\right)\end{array}$ & Salinity & $\begin{array}{l}\mathrm{NO}_{2}+ \\
\mathrm{NO}_{3}(\mu \mathrm{M})\end{array}$ & $\begin{array}{l}\mathrm{PO}_{4} \\
(\mu \mathrm{M})\end{array}$ & $\begin{array}{l}\mathrm{BP} \\
\left(\mu \mathrm{gC} \mathrm{L}^{-1} \mathrm{~d}^{-1}\right)\end{array}$ & $\begin{array}{l}\text { PP } \\
\left(\mu g \mathrm{CL}^{-1} \mathrm{~d}^{-1}\right)\end{array}$ & $\begin{array}{l}\mathrm{N}_{2} \text { fixation } \\
\text { (nmol } \mathrm{N} \\
\left.\mathrm{L}^{-1} \mathrm{~d}^{-1}\right)\end{array}$ & $\begin{array}{l}\text { Contribution of } \\
\text { layer to total } \mathrm{N}_{2} \\
\text { fixation (\%) }\end{array}$ \\
\hline \multirow[t]{2}{*}{ Gulf of Aqaba } & Photic & Mixed & $22-23$ & $40.5-40.7$ & $0.09-0.90$ & BLD-0.04 & $0.4-0.8$ & $0.1-3.1$ & $0.05-0.11$ & 63 \\
\hline & & Stratified & $23-27$ & $40.5-40.8$ & $0.04-0.06$ & BLD-0.04 & $1.5-3.8$ & $0.3-0.6$ & $0.35-0.63$ & 25 \\
\hline \multirow[t]{2}{*}{ Levantine basin } & & Mixed & $17-18$ & $39.1-39.2$ & $0.06-0.46$ & $0.02-0.10$ & $0.4-0.5$ & $0.7-2.3$ & BLD-0.01 & 44 \\
\hline & & Stratified & $18-28$ & $39.2-39.5$ & BLD-0.20 & BLD-0.03 & $0.4-2.5$ & $0.4-1.8$ & $0.01-0.17$ & N.A \\
\hline \multirow[t]{2}{*}{ Gulf of Aqaba } & Aphotic & Mixed & $21-22$ & $40.5-40.7$ & $0.80-5.61$ & $0.04-0.36$ & $0.2-0.4$ & $0-0.1$ & $0.02-0.20$ & 37 \\
\hline & & Stratified & $21-23$ & $40.4-40.7$ & $0.06-6.24$ & $0.04-0.36$ & $0.5-2.4$ & 0 & $0.07-0.38$ & 75 \\
\hline \multirow[t]{2}{*}{ Levantine basin } & & Mixed & 14-18 & 38.9-39.1 & $0.20-4.31$ & $0.10-0.25$ & $0.8-2.7$ & $0.3-0.5$ & $0.01-0.02$ & 56 \\
\hline & & Stratified & 15-18 & $38.9-39.1$ & $0.10-4.52$ & $0.10-0.20$ & $4.6-10.7$ & N.A & $0.01-0.24$ & N.A \\
\hline
\end{tabular}

N.A, not available, BLD, below detection limit.

\section{AMINO-ACIDS ENRICHMENT EXPERIMENT}

We assumed that enriching the water with amino acids would promote conditions that were advantageous to heterotrophic bacteria in general and also to heterotrophic diazotrophs. We assumed that if heterotrophic diazotrophic bacteria were limited by energy (carbon), the addition of high-carbon containing amino acids would alleviate this limitation allowing these populations to fix $\mathrm{N}_{2}$. The idea was to distinguish general bacterial heterotrophic activity (bacterial production rates) from diazotrophic ones ( $\mathrm{N}_{2}$ fixation rates). The response of the microbial community to additions of an amino acid mixture (Sigma A9906) was tested at 4 aphotic $(160,300,500,720 \mathrm{~m})$ and two photic $(10,85)$ depths (Tables 1, 2) during July 2012 in the GA. Amino acids were added to $4.5 \mathrm{~L}$ polycarbonate Nalgene bottles filled with whole water from a specified depth at a final concentration of $500 \mathrm{nM}$ C immediately prior to making ${ }^{15} \mathrm{~N}_{2}$ additions.

\section{PYROSEOUENCING}

DNA was extracted from a representative aphotic depth in the LB stations. Fifteen L of seawater were filtered onto $0.2 \mu \mathrm{m}$ Supor ${ }^{\circledR}$ filter (PALL) and stored in $-80^{\circ} \mathrm{C}$ until analysis in the lab. DNA was extracted using a genomic DNA kit (Roche) and the extract was purified with a QIAGEN purification kit according to the manufacturer's instructions. Amplification of nif $\mathrm{H}$ genes from genomic DNA was performed as described elsewhere (Zehr and McReynolds, 1989). The nifH sequences retrieved from the pyrosequencing analyses [performed by Research and Testing Laboratories (MRDNA, Texas, USA)] were trimmed and checked for quality using QIIME (Caporaso et al., 2010). The cleaned sequences were compared to a nifH database (Zehr et al., 2003). In the aphotic layer of the LB only 20 sequences with an open reading frame were retrieved. These sequences were further confirmed using BLASTX (Altschul et al., 1990) with a cutoff of $95 \%$. The nifH-like sequences were integrated into a nifH phylogenetic tree created with MEGA 4.0 software described in details by Tamura et al. (2007). nifH gene sequences were submitted to GeneBank and were assigned the accession numbers KC222033-KC222052.

\section{DETERMINATION OF TRANSPARENT EXOPOLYMER PARTICLES (TEP) CONCENTRATION AND SIZE}

Triplicate water samples $(100 \mathrm{ml})$ were filtered onto a $0.4 \mu \mathrm{m}$ polycarbonate filters and stained for $2 \mathrm{~s}$ with a $0.02 \%$ Alcian Blue solution. TEP concentrations ( $\mu \mathrm{g}$ GX equivalents $\mathrm{L}^{-1}$ ) were measured according to Passow and Alldredge (1995). A conversion factor of 0.51 was used to convert from micrograms of Gum Xanthan (GX) equivalents to micrograms of carbon (Engel and Passow, 2001).

For TEP size $\left(\operatorname{area}-\mu \mathrm{m}^{2}\right)$ measurements, samples $(100 \mathrm{ml})$ were filtered gently ( $\sim 100 \mathrm{mbar}$ ) onto $0.4 \mu \mathrm{m}$ polycarbonate filters, stained for $10 \mathrm{~s}$ with freshly prepared Alcian Blue solution $(0.02 \%)$, rinsed with $5 \mathrm{ml}$ of double distilled water (DDW), placed onto microscope slides and kept at $4^{\circ} \mathrm{C}$. The filters were analyzed under X40 magnification after 1-2 days and at least 90 pictures per slide were taken. The pictures were analyzed with image J software (http://rsbweb.nih.gov/ij/) to determine the size of TEP.

\section{TEP ENRICHMENT EXPERIMENT}

The association of aphotic diazotrophs with TEP was explored by adding 4 different quantities of pure GX (Sigma G1253) to LB seawater taken from $250 \mathrm{~m}$ (March 2013). Three replicate bottles were tested per treatment and per unamended controls containing seawater only. The bottles were incubated in the dark at ambient temperatures $\left(15^{\circ} \mathrm{C}\right)$ for $24 \mathrm{~h}$, after which they were sampled to measure TEP concentration and size and rates of $\mathrm{N}_{2}$ fixation and BP.

\section{STATISTICAL ANALYSES}

Data were displayed as means with corresponding standard deviations for correlation and regression analyses between variables. Comparisons between unamended controls (no addition) and the amended microcosms (+Dissolved free amino-acids, DFAA) at the end of the experiment, a One-Way ANOVA followed by Tukey's multiple comparison post hoc using R software (www.r-project.org). $P<0.05$ was considered statistically significant. 


\section{RESULTS}

\section{PHYSICAL AND CHEMICAL CHARACTERISTICS OF THE APHOTIC LAYER}

The aphotic layer was determined at each station as the depth below which irradiance was $<0.1 \%$ of surface irradiance. The depths of the photic layer varied between stations and seasons, ranging from $105 \mathrm{~m}$ to $140 \mathrm{~m}$ at both sampling locations (Table 1). Temperature and salinity in the aphotic layer of the GA station were $21.5 \pm 0.5^{\circ} \mathrm{C}$ and $40.6 \pm 0.1$, respectively during both the mixed (winter) and stratified (summer) periods. In the photic layer of the GA, temperatures were $22 \pm 0.5^{\circ} \mathrm{C}$ during winter and $25 \pm 2{ }^{\circ} \mathrm{C}$ during the stratified months (Figures 1A,B; Table 2). At the LB station, temperatures and salinities of the aphotic layer were significantly lower than those measured for the GA station, averaging $16.1 \pm 1.1^{\circ} \mathrm{C}$ and $39.1 \pm 0.1$, respectively (Figures 1C,D; Table 2), while within the photic layer temperature and salinities averaged $23 \pm 5^{\circ} \mathrm{C}$ and $39.3 \pm 0.2$, respectively, during the stratified period (Figures 1C,D; Table 2).

Average dissolved $\mathrm{NO}_{3}$ concentrations in the nitricline and sub-nitricline depths of the GA were $3.0 \pm 2.1 \mu \mathrm{M}$ with the nutricline ranging between $200-400 \mathrm{~m}$ during the winter mixing $(n=9$, Figure 1A; Table 2$) . \mathrm{NO}_{3}$ concentrations remained similar $(3.0 \pm 2.5 \mu \mathrm{M})$ during the stratified summer for the same depths although the nutricline deepened to $150-500 \mathrm{~m}(n=13$, Figure 1B; Table 2). $\mathrm{PO}_{4}$ (DIP) concentrations varied similarly in both periods, averaging $0.2 \pm 0.2 \mu \mathrm{M}$ (Figures 1A,B; Table 2).
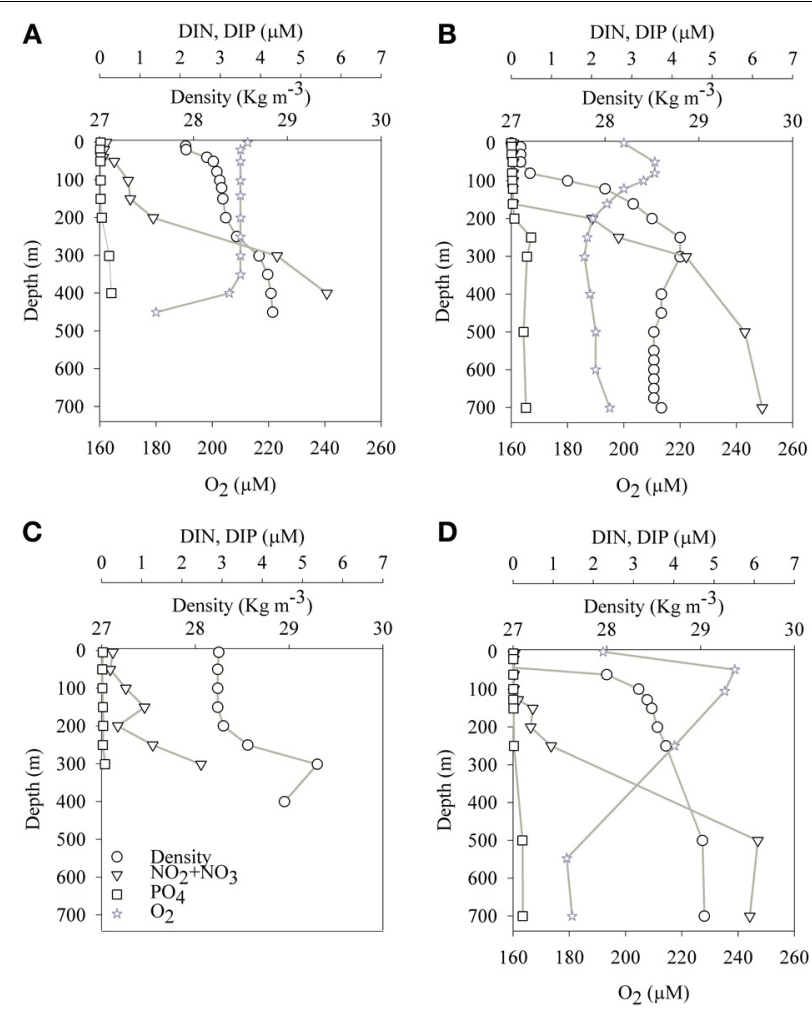

FIGURE 1 | Spatial (depth) and temporal changes of physical and chemical parameters at the sampling stations in the Gulf of Aqaba $(A, B)$ and Levantine basin $(C, D)$ during the mixed $(A, C)$ and stratified (B,D) periods.
Surface $\mathrm{NO}_{3}$ and DIP concentrations were low and close to their detection limit during both periods (Figures 1A,B; Table 2).

Unlike the GA, no seasonal fluctuations in $\mathrm{NO}_{3}$ and DIP concentrations were recorded in the aphotic depths of the pelagic LB station (Figures 1C,D). At these depths lower $\mathrm{NO}_{3}$ and DIP concentrations were $2.2 \pm 2.1 \mu \mathrm{M}$ and $0.1 \pm 0.5 \mu \mathrm{M}$, respectively ( $n=7-9$, Figures 1C,D; Table 2).

\section{$\mathbf{N}_{2}$ FIXATION RATES}

Photic $\mathrm{N}_{2}$ fixation rates compiled from both stations, at all depths and seasons yielded rates usually below $0.1 \mathrm{nmol} \mathrm{N} \mathrm{L^{-1 }}$ $\mathrm{d}^{-1}$ excluding rates measured in the GA during summer $(0.35$ $0.63 \mathrm{nmol} \mathrm{N} \mathrm{L}{ }^{-1} \mathrm{~d}^{-1}$ ) (Table 2). Aphotic $\mathrm{N}_{2}$ fixation rates ranged from 0.01 to $0.38 \mathrm{nmol} \mathrm{N} \mathrm{L} \mathrm{N}^{-1} \mathrm{~d}^{-1}$ at both locations sampled (Table 2). Aphotic rates obtained in the GA during the mixed period ranged from 0.02 to $0.2 \mathrm{nmol} \mathrm{N} \mathrm{L} \mathrm{N}^{-1} \mathrm{~d}^{-1}$ and averaged $0.1 \pm 0.1 \mathrm{nmol} \mathrm{N} \mathrm{L} \mathrm{N}^{-1} \mathrm{~d}^{-1}$ while during the stratified period rates ranged from 0.07 to $0.38 \mathrm{nmol} \mathrm{N} \mathrm{L}^{-1} \mathrm{~d}^{-1}$ and averaged $0.30 \pm 0.10 \mathrm{nmol} \mathrm{N} \mathrm{L}^{-1} \mathrm{~d}^{-1}$ (Table 2). At the LB station, aphotic $\mathrm{N}_{2}$ fixation was uniformly low during the mixed period; $0.01 \pm$ $0.01 \mathrm{nmol} \mathrm{N} \mathrm{L}{ }^{-1} \mathrm{~d}^{-1}$ and increased $\sim 20$-fold during the stratified period to $0.24 \pm 0.09 \mathrm{nmol} \mathrm{N} \mathrm{L}{ }^{-1} \mathrm{~d}^{-1}$ (Table 2).

To understand the significance of aphotic $\mathrm{N}_{2}$ fixation relative to the total areal rates of $\mathrm{N}_{2}$ fixation, we calculated that during our sampling times, $\mathrm{N}_{2}$ fixation from aphotic depths sampled accounted for 37 to $75 \%$ of total areal $\mathrm{N}_{2}$ fixation at the GA station and $\sim 50 \%$ of the total areal $\mathrm{N}_{2}$ fixation at the LB station during the mixed period (Table 2).

\section{PHYTOPLANKTON AND BACTERIAL PRODUCTIVITY RATES}

$\mathrm{PP}$ rates in the GA averaged $3.0 \pm 0.1 \mu \mathrm{g} \mathrm{C} \mathrm{L}^{-1} \mathrm{~d}^{-1}$ and $0.5 \pm$ $0.1 \mu \mathrm{g} \mathrm{C} \mathrm{L}^{-1} \mathrm{~d}^{-1}$ for the mixed and stratified periods, respectively $\left(n=3\right.$, PAR at surface of $1000-1500 \mu \mathrm{mol}$ quanta $\left.\mathrm{m}^{-2} \mathrm{~s}^{-1}\right)$. $\mathrm{PP}$ at the LB station was generally lower; averaging $2.1 \pm 0.2 \mu \mathrm{g}$ $\mathrm{C} \mathrm{L} \mathrm{L}^{-1} \mathrm{~d}^{-1}$ and $1.8 \mu \mathrm{g} \mathrm{C} \mathrm{L}^{-1} \mathrm{~d}^{-1}$ for the mixed and stratified periods, respectively $(n=3$, PAR at surface of $1500-1800 \mu \mathrm{mol}$ quanta $\mathrm{m}^{-2} \mathrm{~s}^{-1}$ ) (Table 2). Bicarbonate uptake rates were usually below detection limits within the aphotic zone (below 105-140 m, depending on sampling location) excluding a wintertime measurement in the LB station $(200 \mathrm{~m})$ when $\mathrm{C}$ uptake averaged $0.4 \pm 0.1 \mu \mathrm{g} \mathrm{C} \mathrm{L}^{-1} \mathrm{~d}^{-1}$ (Table 2).

Bacterial productivity $(\mathrm{BP})$ rates in the photic waters from both locations ranged from 0.4 to $3.8 \mu \mathrm{g} \mathrm{C} \mathrm{L}^{-1} \mathrm{~d}^{-1}$, while in the aphotic zone BP rates were 0.2 to $10.7 \mu \mathrm{g} \mathrm{C} \mathrm{L}^{-1} \mathrm{~d}^{-1}$ (Table 2). Rates of $\mathrm{N}_{2}$ fixation from both the photic and aphotic layers were compared to BP and PP (Figure 2). BP correlated significantly and positively with $\mathrm{N}_{2}$ fixation rates within the photic zone of both basins $\left(R^{2}=0.70, P=0.001, n=12\right)$, while there was no apparent correlation between $\mathrm{N}_{2}$ fixation rates and $\mathrm{PP}$ (Figure 2A). Moreover, BP and $\mathrm{N}_{2}$ fixation were also positively correlated within the aphotic depths $\left(R^{2}=0.58, P=0.003, n=\right.$ 10) (Figure 2B).

To further understand what limits $\mathrm{N}_{2}$ fixation by heterotrophic diazotrophs in oligotrophic and aphotic systems we added dissolved free amino acids (DFAA) to microcosm experiments conducted in the oligotrophic stratified period during July 2012 in the GA. In water samples collected from the aphotic layer, DFAA 
additions enhanced BP rates by a factor of 2-3.5 and $\mathrm{N}_{2}$ fixation rates increased by a factor of 1.5-2 (ANOVA, $P<0.05$ ) (Table 3 ). Within the photic layer, the response of bacteria to DFAA additions was greater than that observed in the aphotic zone; BP increased 2- to 6-fold and $\mathrm{N}_{2}$ fixation rates increased by a factor of 2 to 4 (ANOVA, $P<0.05$ ) (Table 3 ).
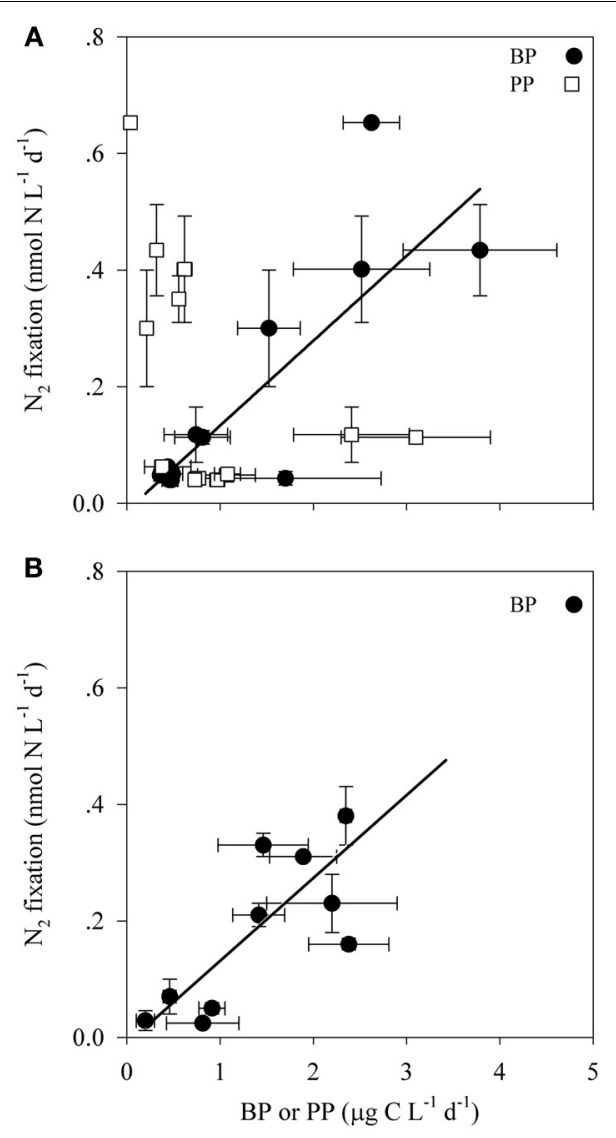

FIGURE 2 | The relationship between $\mathrm{N}_{2}$ fixation and primary and bacterial productivity within the photic $(A)$ and aphotic $(B)$ layers of the LB and GA stations. Values are averages and error bars are standard deviations of three independent replicates performed for each control and treatment incubation.

\section{TEP AS SOURCE OF CARBON OR MICROHABITAT}

TEP concentrations ranged from 100 to $5000 \mu \mathrm{g} \mathrm{GX} \mathrm{L}^{-1}$ and varied in size; the two-dimensional TEP size ranged from 24 to $40 \mu \mathrm{m}^{2}$ with the largest particles measured at TEP concentrations of $\sim 3500 \mu \mathrm{g} \mathrm{GX} \mathrm{L}^{-1}$ (Figure 3). BP increased almost 7-fold, from $\sim 0.6 \mu \mathrm{g} \mathrm{C} \mathrm{L}^{-1} \mathrm{~d}^{-1}$ in the unamended control bottles to $\sim 4 \mu \mathrm{g} \mathrm{C} \mathrm{L} \mathrm{L}^{-1} \mathrm{~d}^{-1}$ in incubations amended with the highest TEP concentrations $\left(5000 \mu \mathrm{g} \mathrm{GX} \mathrm{L}{ }^{-1}\right) . \mathrm{N}_{2}$ fixation was also stimulated ( $\sim 57$-fold) by TEP additions increasing from $0.06 \mathrm{nmol} \mathrm{N}$ $\mathrm{L}^{-1} \mathrm{~d}^{-1}$ in the controls to $3.46 \mathrm{nmol} \mathrm{N} \mathrm{L} \mathrm{N}^{-1} \mathrm{~d}^{-1}$ in the bottles amended with $\sim 3500 \mu \mathrm{g}$ GX L ${ }^{-1} . \mathrm{N}_{2}$ fixation rates were positively correlated with both TEP concentration $\left(R^{2}=0.49, P=\right.$ $0.07, n=15)$ and TEP size $\left(R^{2}=0.90, P=3 \times 10^{-5}, n=15\right)$ (Figure 3).

\section{MOLECULAR DIVERSITY OF $\boldsymbol{n i f H}$}

$\mathrm{NifH}$-like genes were retrieved from the aphotic layer of the LB and were compared with nifH genes from known bacterial isolates. Twenty sequences were retrieved and all clustered together with heterotrophic bacteria and were most similar to Pseudomonas stutzeri (Figure 4). All of our sequences were separated from the autotrophic clusters.

\section{DISCUSSION}

Most marine $\mathrm{N}_{2}$ fixation studies neglect the potential contribution of biological $\mathrm{N}_{2}$ fixation in deep, aphotic, $\mathrm{NO}_{3}$-rich waters that comprise the majority of the world's oceans (Karl et al., 2002; Zehr and Ward, 2002). This is likely because phototrophic and cyanobacterial diazotrophs have an ecological advantage in surface waters where productivity is often limited by the availability of fixed nitrogen yet there is sufficient energy (irradiance) to drive both photosynthetic $\mathrm{C}$ uptake and the costly process of $\mathrm{N}_{2}$ fixation (Howarth et al., 1988; Postgate, 1998; Karl et al., 2002). Currently these assumptions are being modified as significant $\mathrm{N}_{2}$ fixation rates are reported from marine areas with high DIN concentrations (review in Knapp, 2012). Here we provide evidence that aphotic, nitrogen-rich waters also harbor active diazotrophs that contribute substantial new $\mathrm{N}$ to the oceanic $\mathrm{N}$ inventory, and that $\mathrm{N}_{2}$ fixation by these bacterial diazotrophs may be limited by the supply of organic C.

In this study we have documented for the first time significant $\mathrm{N}_{2}$ fixation rates from the aphotic, oxidized waters (Figure 1)of

Table 3 | The effect of dissolved free amino acid (DFAA) enrichments (+ DFAA) on bacterial productivity (BP) and $\mathrm{N}_{2}$ fixation during the stratified summer period (GA, July 2012) within different depths of the photic and aphotic layers.

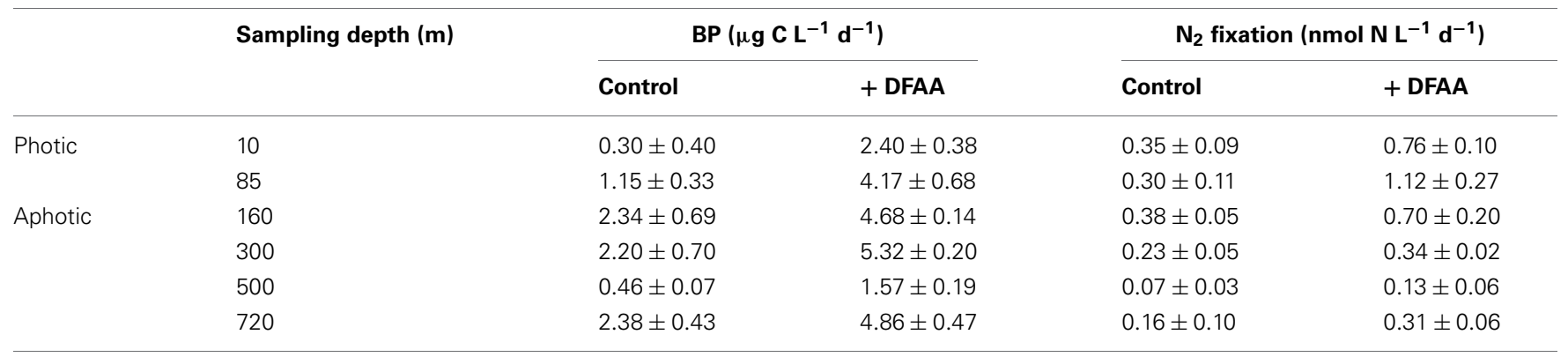

Measurements are based on 3-4 replicates for each sampled depth. 


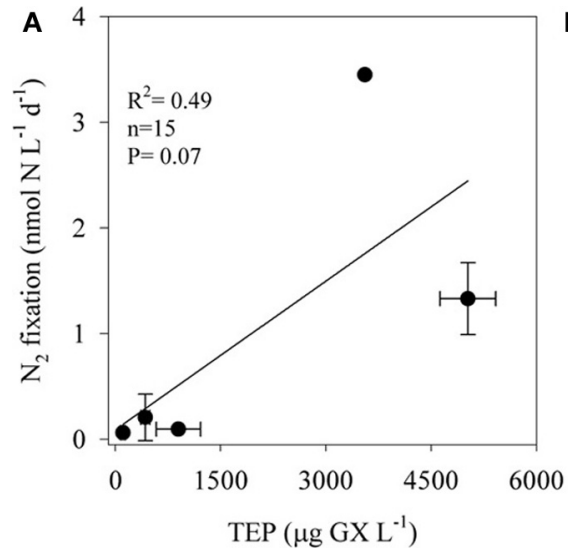

FIGURE 3 | The relationship between $\mathrm{N}_{2}$ fixation rates of aphotic diazotrophs and transparent exopolymer particles (TEP) concentrations $(A)$ and size (B) in experimental manipulations of LB waters from $250 \mathrm{~m}$

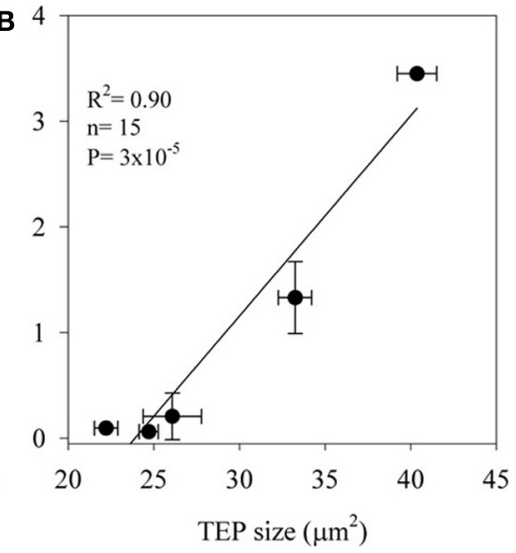

depth to which we added 4 concentrations of pure gum xanthan. Values are averages and error bars are standard deviations of three independent replicates performed for each control and treatment incubation.

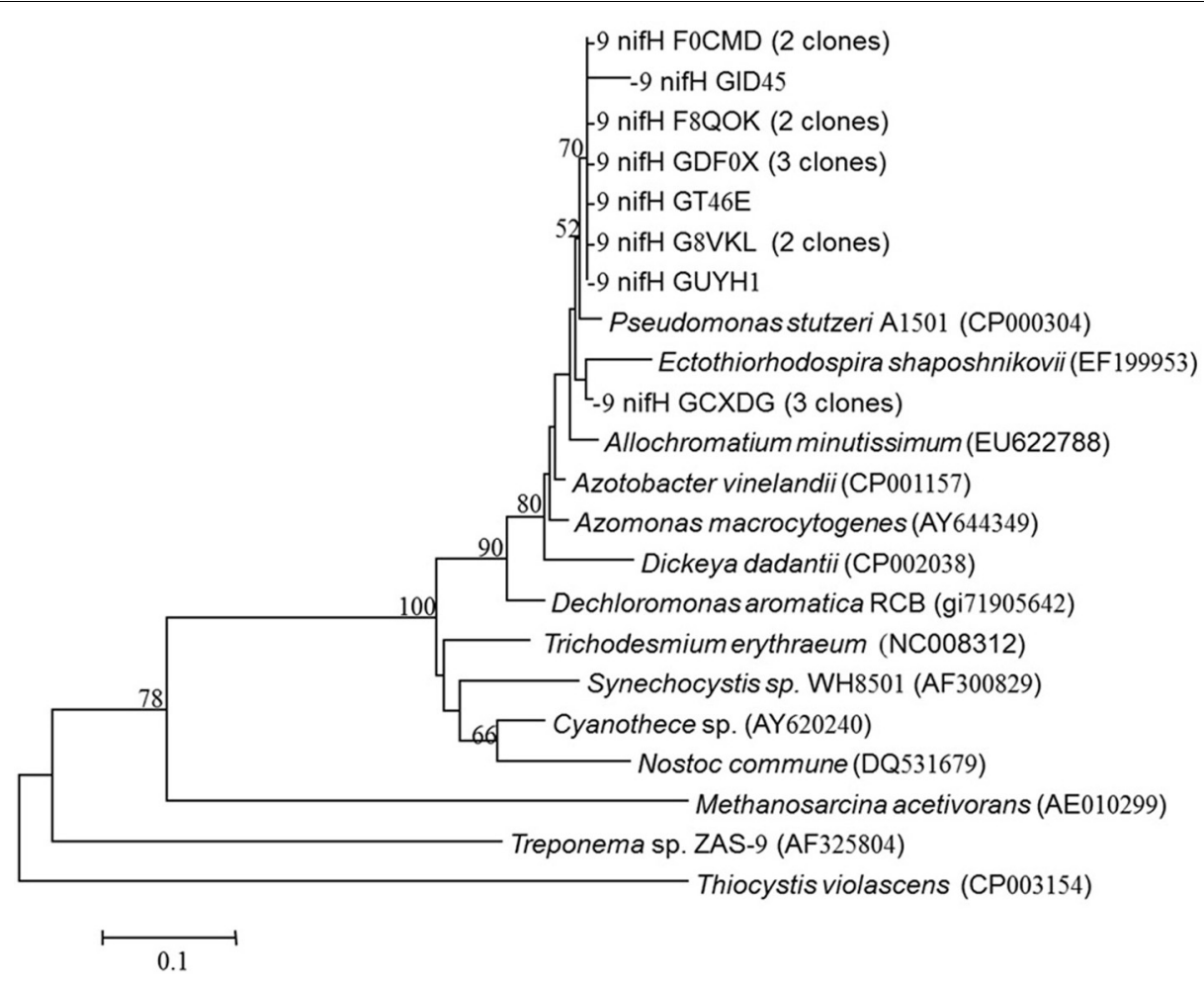

FIGURE 4 | nifH gene tree of clones retrieved from the aphotic layer in the Levantine Basin. Numbers in parentheses represent the number of clones in the library that were identical to the clones in the phylogenetic tree. Bootstrap values above $50 \%$ are indicated above the nodes.

the oligotrophic $\mathrm{LB}$ and the GA. The measured $\mathrm{N}_{2}$ fixation rates in the aphotic waters of both $\mathrm{LB}$ and GA ranged from $0.01 \mathrm{nmol}$ $\mathrm{N} \mathrm{L}^{-1} \mathrm{~d}^{-1}$ to $0.38 \mathrm{nmol} \mathrm{N} \mathrm{L} \mathrm{L}^{-1} \mathrm{~d}^{-1}$. These rates were similar to the $\mathrm{N}_{2}$ fixation rates reported from aphotic depths in the hypoxic Southern California Bight (Hamersley et al., 2011), yet were $\sim 10-100$ fold lower than those measured in the Peruvian upwelling OMZ (Fernandez et al., 2011).
The significance of our measured rates was realized upon integration of water column $\mathrm{N}_{2}$ fixation from surface to the deepest depth sampled (Table 1). Thus, the contribution of aphotic $\mathrm{N}_{2}$ fixation accounted for $\sim 50 \%$ from the total $\mathrm{N}_{2}$ fixation in the LB station, where winter mixing is shallow and the aphotic water hardly mixes with the photic layer, and 37 to $75 \%$ within the GA station (Table 2). 
The substantial role of aphotic $\mathrm{N}_{2}$ fixation in the $\mathrm{LB}$ and the GA may be especially important to basin-wide productivity given the low rates of $\mathrm{N}_{2}$ fixation in the photic layers of both these nutrient-poor environments (Foster et al., 2009; BermanFrank and Rahav, 2012). Within the photic layer, $\mathrm{N}_{2}$ fixation was undetectable in a third of the measurements made in the Eastern Mediterranean Sea during several studies $(n>250)$ spanning seasons and years (Ibello et al., 2010; Yogev et al., 2011). In contrast, measureable rates of $\mathrm{N}_{2}$ fixation were observed in $>90 \%$ of samples collected from the aphotic zone $(n=48)$, regardless of season, thermal stability or depth (Table 2), further emphasizing the importance of $\mathrm{N}_{2}$ fixation in these realms and the requirement for subsequent comprehensive investigations that could constrain modeling efforts.

Our measured aphotic $\mathrm{N}_{2}$ fixation rates may actually represent an underestimate of this process as: (1) our sampling did not cover the full depth of the water column-thus integration may yield higher contribution of aphotic to the total $\mathrm{N}_{2}$ fixation (see methods); (2) we used the common gas bubble enrichment method (Montoya et al., 1996 and see Materials and Methods) which may underestimate $\mathrm{N}_{2}$ fixation rates by a factor of 2-6 compared to the enriched seawater method (Großkopf et al., 2012; Wilson et al., 2012). Early field comparisons from the LB photic waters between the two methods showed a 2-3 fold underestimation by the gas bubble technique (Rahav et al., 2013b). Assuming our aphotic rates were underestimated by a similar ratio of $\sim 50 \%$, our measured aphotic $\mathrm{N}_{2}$ fixation would increase accordingly so that maximal aphotic rates would be $\sim 0.8 \mathrm{nmol} \mathrm{N}$ $\mathrm{L}^{-1} \mathrm{~d}^{-1}$, and with DFAA addition up to $1.4 \mathrm{nmol} \mathrm{N} \mathrm{L}{ }^{-1} \mathrm{~d}^{-1}$. Yet, as the estimated increase by $50 \%$ would also be accounted for in photic rates of $\mathrm{N}_{2}$ fixation, the \% contribution of aphotic to total $\mathrm{N}_{2}$ fixation would remain the same.

Energetic requirements for diazotrophy are high (Postgate, 1998), thus we initially assumed that phototrophic (mainly cyanobacterial) diazotrophs would dominate the photic zone, while at aphotic depths, $\mathrm{N}_{2}$ fixation rates would be extremely low and accomplished by heterotrophic bacterial populations that would be prone to carbon limitation due to the low overlying productivity. However, we found that in the LB and GA stations heterotrophic diazotrophs were the dominant $\mathrm{N}_{2}$ fixers in both photic and aphotic zones. This was confirmed by examining the relationship between $\mathrm{N}_{2}$ fixation and BP and PP (Figure 2), molecular analysis of nifH genes (Figure 4), and the stimulation of $\mathrm{N}_{2}$ fixation after amino acid amendments (Table 3 ). In the stratified photic zone, a significant correlation was found between $\mathrm{BP}$ and $\mathrm{N}_{2}$ fixation $\left(R^{2}=0.70, P=0.001, n=10\right)$ and both were stimulated by the addition of DFAA (Table 3 ). In contrast, no correlation was found between $\mathrm{N}_{2}$ fixation and PP (Figure 2A). Although ample solar irradiance was available, heterotrophic bacterial diazotrophs appear to dominate in this system relying on dissolved and particulate organic carbon (DOC and POC, respectively) as energy sources (Goldthwait et al., 2005; Azam and Malfatti, 2007; Eichinger et al., 2009).

Within the aphotic layer, $\mathrm{N}_{2}$ fixation was positively correlated with $\mathrm{BP}\left(R^{2}=0.58, P=0.003, n=10\right)$, (Figure 2). Moreover, a 2-3 fold enhancement of $\mathrm{N}_{2}$ fixation rates and enhanced $\mathrm{BP}$ were observed following DFAA amendments (Table 3). DFAA are labile dissolved organic carbon (DOC) and nitrogen (DON) sources for microbes (Middelburg and Nieuwenhuize, 2001) that can be directly utilized by bacterial heterotrophs (Davis et al., 2009). Our data thus suggests that the addition of $\mathrm{C}$ and $\mathrm{N}$ sources stimulated both diazotrophic and non-diazotrophic heterotrophic populations. Moreover, the increase in $\mathrm{N}$ source concomitantly with enhanced $\mathrm{N}_{2}$ fixation rates demonstrate that the higher concentration of dissolved $\mathrm{N}$ sources (either DON or bacterially catabolized into DIN) were not sufficient to inhibit diazotrophy. These results highlight the significant role of heterotrophic bacteria as important components of the photic and aphotic diazotrophic community and suggest that the availability of organic matter may limit bacterial diazotrophy in these oligotrophic regimes.

Previous molecular characterization of diazotrophs that were actively expressing nifH genes from the photic zones of the LB and GA demonstrated a diverse array of both heterotrophic bacteria and cyanobacterial phylotypes from Clusters I, II, and III (Foster et al., 2009; Yogev et al., 2011). In this study, phylogenetic analyses of nifH from the aphotic depths indicated that diazotrophs present were within Clusters I and III, phylotypes predominantly comprised of heterotrophic bacteria, including $\alpha$ and $\gamma$ proteobacteria (Chien and Zinder, 1996) (Figure 4). The nifH phylogenetic diversity obtained from the aphotic zone during this study was similar to that recovered from the Southern California Bight (Hamersley et al., 2011) and anaerobic bacteria from the Sargasso Sea (Hewson and Fuhrman, 2007) (Figure 4).

Our results suggest that in the aphotic zones of both LB and GA heterotrophic bacterial $\mathrm{N}_{2}$ fixation is a considerable source of new N. Yet these environments have not heretofore been considered as major sources of new oceanic $\mathrm{N}$ inputs, likely because they are dark, oxygenated, and $\mathrm{NO}_{3}$-rich (Figure 1). Heterotrophic diazotrophs in aphotic areas may be carbon (energy) limited, especially in oligotrophic systems where export of organic particulate matter to depth is low. This is illustrated by the uncoupling between BP and PP observed in our study sites. In this study we demonstrated that $\mathrm{N}_{2}$ fixation and $\mathrm{BP}$ rates were enhanced when DFAA were added (Table 3). In addition to labile organic compounds such as DFAA, the mesopelagic aphotic layer is rich in organic carbon in the form of planktonic microgelatinous marine snow (Azam, 1998; Azam and Malfatti, 2007). This includes protobiofilms that are transparent exopolymer particles (TEP), heavily colonized by bacteria (Bar-Zeev et al., 2011, 2012). In oligotrophic systems these protobiofilm shuttles contribute significantly to the organic carbon pool especially at depths where other $\mathrm{C}$ sources are scarce (Azam and Malfatti, 2007; Ward et al., 2009; Bar-Zeev et al., 2012). While these particles are rich in $\mathrm{C}$, the high $\mathrm{C}: \mathrm{N}$ ratios of TEP (Engel and Passow, 2001; Passow, 2002) make them poor $\mathrm{N}$ sources and would seem to require the use of some $\mathrm{N}$ supplement to foster microbial growth. Heterotrophic $\mathrm{N}_{2}$ fixation could provide an excellent source of $\mathrm{N}$ to fuel microbial growth on, within, and near these particles. Indeed, our data demonstrate a positive relationship between TEP concentration $\left(R^{2}=0.49, P=0.07, n=\right.$ $15)$, TEP size $\left(R^{2}=0.90, P=3 \times 10^{-5}, n=15\right)$, and $\mathrm{N}_{2}$ fixation (Figure 3). The ability to fix $\mathrm{N}_{2}$ could provide diazotrophic 
heterotrophs with a competitive advantage over non-diazotrophic heterotrophic bacteria in carbon-rich and nitrogen-poor microenvironments such as these. Moreover, in aggregates such as marine snow, TEP, and other marine microgels, bacterial colonization causes high metabolic consumption of oxygen and decreasing oxygen gradients from the surface to the anaerobic center (Paerl and Prufert, 1987). Reduced oxygen concentrations would theoretically benefit diazotrophic bacteria because nitrogenase is an oxygen-sensitive protein (Postgate, 1998). We speculate these anaerobic, high $\mathrm{C}$, low $\mathrm{N}$ microenvironments could promote the competitive success and activity of heterotrophic diazotrophs at depth.

Our novel data thus provides a conservative estimate of an additional 37 to $75 \%$ source of $\mathrm{N}$ via aphotic $\mathrm{N}_{2}$ fixation in the oligotrophic Levantine basin and the GA. Our measurements substantiate early indications (Paerl and Prufert, 1987) and recent phylogenetic characterizations (Riemann et al., 2010)

\section{REFERENCES}

Al-Qutob, M., Hase, C., Tilzer, M. M., and Lazar, B. (2002). Phytoplankton drives nitrite dynamics in the Gulf of Aqaba, Red Sea. Mar. Ecol. Prog. Ser. 239, 233-239. doi: 10.3354/meps 239233

Altschul, S. F., Gish, W., Miller, W., Myers, E. W., and Lipman, D. J. (1990). Basic local alignment search tool. J. Mol. Biol. 215, 403-410.

Azam, F. (1998). Microbial control of oceanic carbon flux: the plot thickens. Science 280, 694-696. doi: 10.1126/science.280.5364.694

Azam, F., and Malfatti, F. (2007). Microbial structuring of marine ecosystems. Nat. Rev. Microbiol. 5, 782-791. doi: 10.1038/nrmicro1747

Bar-Zeev, E., Berman, T., Rahav, E., Dishon, G., Herut, B., and BermanFrank, I. (2011). Transparent exopolymer particle (TEP) dynamics in the Eastern Mediterranean Sea. Mar. Ecol. Prog. Ser. 431, 107-118. doi: 10.3354/meps09110

Bar-Zeev, E., Berman-Frank, I., Girshevitz, O., and Berman, T. (2012). Revised paradigm of aquatic biofilm formation facilitated by microgel transparent exopolymer particles. Proc. Natl. Acad. Sci. U.S.A. 109, 9119-9124. doi: 10.1073/pnas. 1203708109

Bar-Zeev, E., Yogev, T., ManAharonovich, D., Kress, N., Herut, B., Béjà, O., et al. (2008). Seasonal dynamics of the endosymbiotic, nitrogen-fixing cyanobacterium Richelia intracellularis in the Eastern Mediterranean Sea. ISME J. 2, 911-923. doi: 10.1038/ismej.2008.56

Bebout, B. M., Paerl, H. W., Crocker, K. M., and Prufert, L. E. (1987). Diel thesis and $\mathrm{N}_{2}$ fixation (acetylenereduction) in a marine microbial mat community. Appl. Environ. Microbiol. 53, 2353-2362.

Berman-Frank, I., and Rahav, E. (2012). "Nitrogen fixation as a source for new production in the Mediterranean Sea: a review," in Life in the Mediterranean Sea: A Look at Habitat Changes, ed N. E. Stambler (New York, NY: Nova Science Publishers), 199-226.

Brooks, R. H., Brezonik, P. L., Putnam, H. D., and Keirn, M. A. (1971). Nitrogen fixation in an estuarine environment: the Waccasassa on Florida Gulf coast. Limnol. Oceanogr. 16, 701-710. doi: 10.4319/lo.1971.16.5.0701 seagrass communities. Mar. Technol. Soc. J. 17, 32-37.

Caporaso, J. G., Kuczynski, J., Stombaugh, J., Bittinger, K., Bushman, F. D., Costello, E. K., et al. (2010). QIIME allows analysis of high-throughput community sequencing data. Nat. Methods 7, 335-336. doi: 10.1038/nmeth.f.303

Carpenter, E. J., and Capone, D. (2008). "Nitrogen fixation in the marine environment," in Nitrogen Fixation in the Marine Environment, eds D. Capone, A. D. Bronk, R. M. Mulholland, and E. J. Carpenter (San Diego, CA: Elsevier Academic Press), 141-198.

Chien, Y. T., and Zinder, S. H. (1996). Cloning, functional organization, transcript studies, and phylogenetic analysis of the complete nitrogenase structural genes (nifHDK2) and associated genes in the archaeon Methanosarcina barkeri 227. J. Bacteriol. 178, 143-148. interactions of oxygenic photosyn-

Capone, D. G. (1983). $\mathrm{N}_{2}$ fixation in

highlighting a pivotal ecological role for diazotrophs in deep, oxygenated, $\mathrm{NO}_{3}$-rich waters. Because these areas comprise the bulk of the world's oceans they could represent a hitherto unaccounted for source of new $\mathrm{N}$ that may contribute to global productivity and could reduce the existing discrepancies [along with other newly described contributions of $\mathrm{N}_{2}$ fixation (reviewed in Knapp, 2012)] between sources and losses of $\mathrm{N}$ found in global marine $\mathrm{N}$ budgets.

\section{ACKNOWLEDGMENTS}

We thank the Inter University Institute for Marine Sciences in Eilat and the Eco-Ocean foundation. We thank Prof. Oded Béjà for bioinformatic help and Adi Levi and Yosef Krausz for technical work. This research was supported by the Israel Science Foundation grants (996/08) to Ilana Berman-Frank and Barak Herut and National Science Foundation (USA) grants to Margaret R. Mulholland.

Codispoti, L. A., Brandes, J. A. Christensen, J. P., Devol, A. H. Naqvi, S. W. A., Paerl, H. W. et al. (2001). The oceanic fixed nitrogen and nitrous oxide budgets: moving targets as we enter the anthropocene. Sci. Mar. 65, 85-105.

Davis, J., Kaiser, K., and Benner, R. (2009). Amino acid and amino sugar yields and compositions as indicators of dissolved organic matter diagenesis. Org. Geochem. 40, 343-352. doi: 10.1016/j.orggeochem.2008.12.003

Deutsch, C., Sarmiento, J. L., Sigman, D. M., Gruber, N., and Dunne, J. P. (2007). Spatial coupling of nitrogen inputs and losses in the ocean. Nature 445, 163-167. doi: 10.1038/nature05392

Eichinger, M., Kooijman, S. A. L. M., Sempere, R., Lefevre, D., Gregori, G., Charriere, B., et al. (2009). Consumption and release of dissolved organic carbon by marine bacteria in a pulsed-substrate environment: from experiments to modeling. Aquat. Microb. Ecol. 56, 41-54. doi: 10.3354/ame01312

Engel, A., and Passow, U. (2001). Carbon and nitrogen content of transparent exopolymer particles (TEP) in relation to their Alcian Blue adsorption. Mar. Ecol. Prog. Ser. 219, 1-10. doi: 10.3354/meps 219001

Eugster, O., and Gruber, N. (2012) A probabilistic estimate of global marine N-fixation and denitrification. Global Biogeochem. Cycles 26. doi: 10.1029/2012GB004300

Falkowski, P. G. (1997). Evolution of the nitrogen cycle and its influence on the biological sequestration of $\mathrm{CO}_{2}$ in the ocean,
Nature 387, 272-275. doi: 10.1038/ 387272a0

Fernandez, C., Farías, L., and Ulloa, O. (2011). Nitrogen fixation in denitrified marine waters. PLoS ONE 6:e20539. doi:10.1371/journal.pone.0020539

Flores, E., and Herrero, A. (2005). Nitrogen assimilation and nitrogen control in cyanobacteria. Biochem. Soc. Trans. 33, 164-167. doi: 10.1042/BST0330164

Foster, R. A., Paytan, A., and Zehr, J. P. (2009). Seasonality of $\mathrm{N}_{2}$ fixation and nifH gene diversity in the Gulf of Aqaba (Red Sea). Limnol. Oceanogr. 54, 219-233. doi: 10.4319/lo.2009.54.1.0219

Goldthwait, S. A., Carlson, C. A., Henderson, G. K., and Alldredge, A. L. (2005). Effects of physical fragmentation on remineralization of marine snow. Mar. Ecol. Prog. Ser. 305, 59-65. doi: 10.3354/meps305059

Großkopf, T., Mohr, W., Baustian, T., Schunck, H., Gill, D., Kuypers, M. M. M., et al. (2012). Doubling of marine dinitrogen-fixation rates based on direct measurements. Nature 488, 361-364. doi: 10.1038 /nature 11338

Gruber, N. (2008). "The marine nitrogen cycle: overview of distributions and processes," in Nitrogen in the Marine Environment, 2nd Edn., eds D. Capone, D. Bronk, M. Mulholland, and E. Carpenter (Amsterdam: Elsevier), 1-50.

Gruber, N., and Galloway, J. N. (2008). An Earth-system perspective of the global nitrogen cycle. Nature 451, 293-296. doi: 10.1038/nature06592

Halm, H., Lam, P., Ferdelman, T. G., Lavik, G., Dittmar, T., Laroche, J., et al. (2012). Heterotrophic 
organisms dominate nitrogen fixation in the South Pacific Gyre. ISME J. 6, 1238-1249. doi: 10.1038/ismej.2011.182

Hamersley, M. R., Turk, K. A., Leinweber, A., Gruber, N., Zehr, J. P., Gunderson, T., et al. (2011). Nitrogen fixation within the water column associated with two hypoxic basins in the Southern California Bight. Aquat. Microb. Ecol. 63, 193-205. doi: 10.3354/ame01494

Herbert, R. A. (1999). Nitrogen cycling in coastal marine ecosystems. FEMS Microb. Rev. 23, 563-590. doi: 10.1111/j.15746976.1999.tb00414.x

Hewson, I., and Fuhrman, J. A. (2007). Covariation of viral parameters with bacterial assemblage richness and diversity in the water column and sediments. Deep Sea Res. I. 54, 811-830. doi: 10.1016/j.dsr.2007.02.003

Howarth, R. W., Marino, R., Lane, J., and Cole, J. J. (1988). Nitrogen-fixation in fresh-water, estuarine, and marine ecosystems.1. rates and importance. Limnol. Oceanogr. 33, 669-687. doi: 10.4319/lo.1988.33.4_part_2.0669

Ibello, V., Cantoni, C., Cozzi, S., and Civitarese, G. (2010). First basinwide experimental results on N2 fixation in the open Mediterranean Sea. Geophys. Res. Lett. 37. doi: 10.1029/2009gl041635.

Jayakumar, A., Al-Rshaidat, M. M. D., Ward, B. B., and Mulholland, M. R. (2012). Diversity, distribution, and expression of diazotroph nifH genes in oxygen-deficient waters of the Arabian Sea. FEMS Microbiol. Ecol. 82, 597-606. doi: 10.1111/j.15746941.2012.01430.x

Karl, D., Michaels, A., Bergman, B., Capone, D., Carpenter, E., Letelier, R., et al. (2002). Dinitrogen fixation in the world's oceans. Biogeochemistry 57, 47-98. doi: 10.1023/A:1015798105851

Knapp, A. N. (2012). The sensitivity of marine $\mathrm{N}_{2}$ fixation to dissolved inorganic nitrogen. Front. Microbiol. 3:374. doi: 10.3389/fmicb.2012.00374

Kress, N., and Herut, B. (2001). Spatial and seasonal evolution of dissolved oxygen and nutrients in the Southern Levantine Basin (Eastern Mediterranean Sea): chemical characterization of the water masses and inferences on the N: P ratios. Deep Sea Res. I. 48, 2347-2372. doi: $\quad 10.1016 /$ S0967-0637 (01)00022-X

Krom, M. D., Emeis, K. C., and Van Cappellen, P. (2010). Why is the Eastern Mediterranean phosphorus limited. Prog. Oceanogr. 85, 236-244. doi: 10.1016/j.pocean.2010.03.003

Langlois, R. J., Laroche, J., and Raab, P. A. (2005). Diazotrophic diversity and distribution in the tropical and subtropical Atlantic Ocean. Appl. Environ. Microbiol. 71, 7910-7919. doi: $\quad$ 10.1128/AEM.71.12.79107919.2005

Man-Aharonovich, D., Kress, N., Bar-Zeev, E., Berman-Frank, I., and Beja, O. (2007). Molecular ecology of nifH genes and transcripts in the Eastern Mediterranean Sea. Environ. Microbiol. 9, 2354-2363. doi: 10.1111/j.14622920.2007.01353.x

McGlathery, K. J. (2008). "The marine nitrogen cycle: overview of distributions and processes," in Nitrogen in the Marine Environment, 2nd Edn., eds D. Capone, D. Bronk, M. Mulholland, and E. Carpenter (Amsterdam: Elsevier), 1037-1071.

Mehta, M. P., and Baross, J. A. (2006). Nitrogen fixation at 92 degrees $\mathrm{C}$ by a hydrothermal vent archaeon. Science 314, 1783-1786. doi: 10.1126/science.1134772

Mehta, M. P., Huber, J. A., and Baross, J. A. (2005). Incidence of novel and potentially archaeal nitrogenase genes in the deep Northeast Pacific Ocean. Environ. Microbiol. 7, 1525-1534. doi: 10.1111/j.14622920.2005.00836.x

Middelburg, J. J., and Nieuwenhuize, J. (2001). Nitrogen isotope tracing of dissolved inorganic nitrogen behavior in tidal estuaries. Estuar. Coast. Shelf S. 53, 385-391. doi: 10.1006/ecss.2001.0805

Mohr, W., Grosskopf, T., Wallace, D. W. R., and Laroche, J. (2010). Methodological underestimation of oceanic nitrogen fixation rates. PLoS ONE 5:e12583. doi: 10.1371/journal.pone. 0012583

Moisander, P. H., Beinart, R. A., Hewson, I., White, A. E., Johnson, K. S., Carlson, C. A., et al. (2010). Unicellular cyanobacterial distributions broaden the oceanic $\mathrm{N}_{2}$ fixation domain. Science 327, 1512-1514. doi: 10.1126/science. 1185468

Montoya, J. P., Voss, M., Kahler, P., and Capone, D. G. (1996). A simple, high-precision, high-sensitivity tracer assay for $\mathrm{N}_{2}$ fixation. Appl. Environ. Microbiol. 62, 986-993.

Mulholland, M. R., and Bernhardt, P. W. (2005). The effect of growth rate, phosphorus concentration, and temperature on $\mathrm{N}_{2}$ fixation, carbon fixation, and nitrogen release in continuous cultures of Trichodesmium IMS101. Limnol. Oceanogr. 50, 839-849. doi: 10.4319/lo.2005.50.3.0839

Mulholland, M. R., Bernhardt, P. W., Blanco-Garcia, J. L., Mannino, A., Hyde, K., Mondragon, E., et al. (2012). Rates of dinitrogen fixation and the abundance of diazotrophs in North American coastal waters between Cape Hatteras and Georges Bank. Limnol. Oceanogr. 57, 1067-1083. doi: 10.4319/lo.2012.57.4.1067

Mulholland, M. R., Bernhardt, P. W., Heil, C. A., Bronk, D. A., and O'Neil, J. M. (2006). Nitrogen fixation and release of fixed nitrogen by Trichodesmium spp in the Gulf of Mexico. Limnol. Oceanogr. 51, 1762-1776. doi: 10.4319/lo.2006.51.4.1762

Mulholland, M. R., and Capone, D. G. (1999). Nitrogen fixation, uptake and metabolism in natural and cultured populations of Trichodesmium spp. Mar. Ecol. Prog. Ser. 188, 33-49. doi: 10.3354/meps 188033

Mulholland, M. R., Ohki, K., and Capone, D. G. (2001). Nutrient controls on nitrogen uptake and metabolism by natural populations and cultures of Trichodesmium (Cyanobacteria). J. Phycol. 37, 1001-1009. doi: 10.1046/j.1529-8817.2001.00080.x

O'Neil, J. M., and Capone, D. G. (2008). "Nitrogen Cycling in Coral Reef Environments," in Nitrogen in the Marine Environment, 2nd Edn., eds D. Capone, D. Bronk, M. Mulholland, and E. Carpenter. (Amsterdam: Elsevier), 949-989.

Orcutt, K. M., Lipschultz, F., Gundersen, K., Arimoto, R., Michaels, A. F., Knap, A. H., et al. (2001). A seasonal study of the significance of $\mathrm{N}_{2}$ fixation by Trichodesmium spp. at the Bermuda Atlantic Time-series Study (BATS) site. Deep Sea Res. I. 48, 1583-1608.

Paerl, H., and Prufert, L. E. (1987). Oxygen-poor microzones as potential sites of microbial $\mathrm{N}_{2}$ fixation in nitrogen-depleted aerobic marine waters. Appl. Environ. Microbiol. 53, 1078-1087.

Passow, U. (2002). Production of transparent exopolymer particles (TEP) by phyto- and bacterioplankton. Mar. Ecol. Prog. Ser. 236, 1-12. doi: 10.3354/meps236001

Passow, U., and Alldredge, A. L. (1995). A dye-binding assay for the spectrophotometric measurement of transparent exopolymer particles (TEP).
Limnol. Oceanogr. 40, 1326-1335. doi: $10.4319 /$ lo.1995.40.7.1326

Paytan, A., Mackey, K. R. M., Chen, Y., Lima, I. D., Doney, S. C., Mahowald, N., et al. (2009). Toxicity of atmospheric aerosols on marine phytoplankton. Proc. Natl. Acad. Sci. U.S.A 106, 4601-4605. doi 10.1073/pnas.0811486106

Post, A. F., Dedej, Z., Gottlieb, R., Li, H., Thomas, D. N., El-Absawi, M. et al. (2002). Spatial and temporal distribution of Trichodesmium spp in the stratified Gulf of Aqaba, Red Sea. Mar. Ecol. Prog. Ser. 239, 241-250. doi: 10.3354/meps239241

Postgate, J. (1998). "Nitrogen fixation," in Nitrogen Fixation, 3rd Edn., ed J. Postgate (London: Cambridge University Press), 124.

Rahav, E., Herut, B., Stambler, N., Bar-Zeev, E., Mulholland, M. R., and Berman-Frank, I. (2013a). Uncoupling between dinitrogen fixation and primary productivity in the Eastern Mediterranean Sea. J. Geophys. Res. 118, 1-8. doi: 10.1002/jgrg.20023

Rahav, E., Herut, B., Levi, A., Mulholland, M. R., and BermanFrank, I. (2013b). Springtime contribution of dinitrogen fixation to primary production across the Mediterranean Sea. Ocean Sci. 9, 1-10. doi: 10.5194/os-9-489-2013

Rees, A. P., Gilbert, J. A., and KellyGerreyn, B. A. (2009). Nitrogen fixation in the western English Channel (NE Atlantic Ocean). Mar. Ecol. Prog. Ser. 374, 7-12. doi: 10.3354/meps07771

Riemann, L., Farnelid, H., and Steward, G. F. (2010). Nitrogenase genes in non-cyanobacterial plankton: prevalence, diversity and regulation in marine waters. Aquat. Microb. Ecol. 61, 225-237. doi: 10.3354/ame01431

Simon, M., Alldredge, A. L., and Azam, F. (1990). Bacterial carbon dynamics on marine snow. Mar. Ecol. Prog. Ser. 65, 205-211. doi: 10.3354/meps065205

Tamura, K., Dudley, J., Nei, M., and Kumar, S. (2007). MEGA4: molecular evolutionary genetics analysis (MEGA) software version 4.0. Mol. Biol. Evol. 24, 1596-1599. doi: 10.1093/molbev/msm092

Tanaka, T., Thingstad, T. F., Christaki, U., Colombet, J., Cornet-Barthaux, V., Courties, C., et al. (2011). Lack of P-limitation of phytoplankton and heterotrophic prokaryotes in surface waters of three anticyclonic eddies in the stratified Mediterranean Sea. Biogeosciences 8, 525-538. doi: 10.5194/bg-8-5252011 
Voss, M., Croot, P., Lochte, K., Mills, M., and Peeken, I. (2004). Patterns of nitrogen fixation along $10 \mathrm{~N}$ in the tropical Atlantic. Geophys. Res. Lett. 31. doi: 10.1029/2004gl020127

Ward, B. B., Devol, A. H., Rich, J. J., Chang, B. X., Bulow, S. E., Naik, H., et al. (2009). Denitrification as the dominant nitrogen loss process in the Arabian Sea. Nature 461, 78-81. doi: $10.1038 /$ nature 08276

Weiss, R. F. (1970). Solubility of nitrogen, oxygen and argon in water and seawater. Deep-Sea Res. 17, 721-735.

Wilson, S. T., Boettjer, D., Church, M. J., and Karl, D. M. (2012). Comparative assessment of nitrogen fixation methodologies, conducted in the oligotrophic North Pacific Ocean. Appl. Environ. Microbiol. 78, 6516-6523. doi: 10.1128/AEM.01146-12

Wu, J. F., Chung, S.-W., Wen, L.-S., Liu, K.-K., Chen, Y.-L. L., Chen, H.-Y., et al. (2003). Dissolved inorganic phosphorus, dissolved iron, and Trichodesmium in the oligotrophic South China Sea. Global Biogeochem. Cycles 17:1008. doi: 10.1029/2002GB001924

Yogev, T., Rahav, E., Bar-Zeev, E., ManAharonovich, D., Stambler, N., Kress, N., et al. (2011). Is dinitrogen fixation significant in the Levantine Basin, East Mediterranean Sea. Environ. Microbiol. 13, 854-871. doi: 10.1111/j.1462-2920. 2010.02402.x

Zehr, J. P., Bench, S. R., Carter, B. J., Hewson, I., Niazi, F., Shi, T., et al. (2008). Globally distributed uncultivated oceanic N2-fixing cyanobacteria lack oxygenic Photosystem, II. Science 322, 1110-1112. doi: 10.1126/science.1165340

Zehr, J. P., Jenkins, B. D., Short, S M., and Steward, G. F. (2003). Nitrogenase gene diversity and microbial community structure: a cross-system comparison.
Environ. Microbiol. 5, 539-554. doi: 10.1046/j.1462-2920.2003.00451.x

Zehr, J. P., and McReynolds, L. A. (1989). Use of degenerate oligonucleotides for amplification of the nifH gene from the marine cyanobacterium Trichodesmiumthiebautii. Appl. Environ. Microbiol. 55, 2522-2526.

Zehr, J. P., and Ward, B. B. (2002). Nitrogen cycling in the ocean: new perspectives on processes and paradigms. Appl. Environ. Microbiol. 68, 1015-1024. doi: 10.1128/AEM.68.3.1015-1024.2002

Conflict of Interest Statement: The authors declare that the research was conducted in the absence of any commercial or financial relationships that could be construed as a potential conflict of interest.

Received: 15 June 2013; accepted: 26 July 2013; published online: 27 August 2013.
Citation: Rahav E, Bar-Zeev E, Ohayon $S$, Elifantz $H$, Belkin $N$, Herut $B$, Mulholland MR and Berman-Frank I (2013) Dinitrogen fixation in aphotic oxygenated marine environments. Front. Microbiol. 4:227. doi: 10.3389/fmicb. 2013.00227

This article was submitted to Aquatic Microbiology, a section of the journal Frontiers in Microbiology.

Copyright (C) 2013 Rahav, Bar-Zeev, Ohayon, Elifantz, Belkin, Herut, Mulholland and Berman-Frank. This is an open-access article distributed under the terms of the Creative Commons Attribution License (CC BY). The use, distribution or reproduction in other forums is permitted, provided the original author(s) or licensor are credited and that the original publication in this journal is cited, in accordance with accepted academic practice. No use, distribution or reproduction is permitted which does not comply with these terms. 